Hypothesis

\title{
The Usefulness of Rare Blood Group Systems in the Risk Determination for Severe COVID-19
}

\author{
Theocharis G. Konstantinidis ${ }^{1,2, *(\mathbb{D}}$, Valeria Iliadi ${ }^{3}$, Georges Martinis ${ }^{1}$ and Maria Panopoulou ${ }^{2}$ \\ 1 Blood Transfusion Center, University General Hospital of Alexandroupolis Dragana Campus, \\ 68100 Alexandroupolis, Greece; geomimar@gmail.com \\ 2 Laboratory of Microbiology, Democritus University of Thrace, University General Hospital of \\ Alexandroupolis Dragana Campus, 68100 Alexandroupolis, Greece; mpanopou@med.duth.gr \\ 3 Izhevsk State Medical Academy, Kommunarov Street 281, 426034 Izhevsk, Russia; iliadi.valeria@mail.ru \\ * Correspondence: tkonsta@med.duth.gr; Tel.: +30-2551352005
}

Citation: Konstantinidis, T.G.; Iliadi, V.; Martinis, G.; Panopoulou, M. The Usefulness of Rare Blood Group Systems in the Risk Determination for Severe COVID-19. Pathophysiology 2021, 28, 496-500. https://doi.org/ $10.3390 /$ pathophysiology 28040032

Academic Editor: Jonathan Steven Alexander

Received: 7 August 2021

Accepted: 2 November 2021

Published: 3 November 2021

Publisher's Note: MDPI stays neutral with regard to jurisdictional claims in published maps and institutional affiliations.

Abstract: The newly identified human coronavirus was named severe acute respiratory syndrome coronavirus 2 (SARS-CoV-2), based on a detailed analysis of clinical manifestation. It was reported that blood type $\mathrm{O}$ individuals were less likely to become infected by SARS-CoV, while blood type A individuals have an increased risk of severe illness. The Forssman antigen, or Forssman glycolipid synthase (FS), was first described in 1911 by John Frederick Forssman. Blood type A/B glycosyltransferases (AT/BTs) and Forssman glycolipid synthase (FS) are encoded by the evolutionarily related $\mathrm{ABO}$ (A/B alleles) and GBGT1 genes. In this article, based on published studies about the pathogenesis of the COVID-19, we hypothesize the possible relationship between the COVID-19 infection and rare blood type systems, such as the Forssman antigen system.

Keywords: COVID-19; Forssman antigen; blood type

\section{Introduction}

The newly identified human coronavirus—-based on the detailed analysis of clinical manifestation-was named severe acute respiratory syndrome coronavirus 2 (SARS-CoV-2) by the World Health Organization (WHO) and the International Committee on Taxonomy of Viruses (ICTV) [1]. Historically, the study of coronaviruses (CoV) started in the 1970s, with a small researcher community. The first international conference, organized by Volker ter Meulen, met in Wurzburg, Germany in the fall of 1980 [2]. Based on their genomic structure, four main subgroups (alpha, beta, gamma, and delta) were described [3]. CoVs are an enveloped positive-stranded RNA virus. The name was taken for the glycoprotein on their surface arranged in crown-like spikes. All coronaviruses have a spherical structure. The virion consists of transmembrane trimeric spike (S) glycoproteins, a membrane glycoprotein $(\mathrm{M})$, and a transmembrane envelope (E) protein. The RNA is bound to the nucleocapsid protein $(\mathrm{N})$ [4]. The interactions between the SARS-CoV spike protein receptor-binding domain (RBD) and its host cellular receptor regulate both the cross-species and humanto-human transmissions of SARS-CoV [5]. The cellular receptor used by coronaviruses to enter into the host cell differs between different coronaviruses. In 1991, Kathryn Holmes identified the MHV receptor as CEACAM1a (MHVR), a carcinoembryonic antigen family member that is responsible for virus-induced cell fusion [6]. Furthermore, receptors were identified as follows: ACE2 for SARS-CoV, DPP4 for MERS-CoV. It was found that ACE2 is also used by SARS-CoV-2 [7].

Human coronaviruses $(\mathrm{CoV})$ cause both upper and lower respiratory tract infections. In the last two decades, two CoVs, named SARS-CoV and MERS-CoV, have been associated with severe human illnesses in 2002 and 2013, respectively [8,9]. The novel coronavirus disease (COVID-19), the severe acute respiratory syndrome coronavirus 2 (SARS-CoV-2), was first reported as cluster of cases in Wuhan, China in December 2019 [10]. On 11 March 2020, 
the World Health Organization characterized the global health emergency of COVID-19 as a pandemic. As of 27 July 2020, the spread of SARS-CoV-2 had resulted in 16,114,449 confirmed cases globally, with 646,641 registered deaths associated with COVID-19 [11]. SARS-CoV-2 is an enveloped positive-stranded RNA virus like other COVs; however, in contrast to others, it is highly contagious in human-to-human transmission [12].

The clinical manifestation of COVID-19 ranges from asymptomatic infection to acute respiratory distress syndrome with system complications and death [10]. The most common symptoms are fever, cough, expectoration, chest distress, fatigue, and gastroenterological symptoms [10,13]. Moreover, studies showed that COVID 19 triggers coagulopathy, since it is associated with the imbalance of host immune response and endothelial damage $[14,15]$.

\section{The ABO System and COVID-19}

It was reported that severe acute respiratory syndrome coronavirus (SARS-CoV) replicates in cells that can express ABO blood type antigens [16]. Moreover, it was indicated previously that blood type $\mathrm{O}$ individuals were less likely to become infected by SARS-CoV, while blood type A individuals have an increased risk of severe illness [17].

Recently, the Severe COVID-19 GWAS Group identified a gene cluster as a genetic susceptibility locus in patients with COVID-19 and confirmed a potential involvement of the $\mathrm{ABO}$ blood type in pathogenesis of disease. They showed a higher risk in blood type A than in other blood types (odds ratio, $1.45 ; 95 \% \mathrm{CI}, 1.20$ to $1.75 ; p=1.48 \times 10^{-4}$ ) and a protective effect in blood type $\mathrm{O}$ in comparison to other blood groups [18].

The Forssman antigen or Forssman glycolipid synthase (FS), was first described in 1911 by John Frederick Forssman [19]. The gene that codes the FS Ag was discovered in 1996 and was named the GBGT1 gene [20]. The human GBGT1 gene is located on chromosome 9 (9q34) and comprises 347 amino acids [21]. This gene has seven exons that span more than $8 \mathrm{~kb}$ of DNA, and the coding region is shared by all species that are positive for the FORS Ag. Furthermore, blood type A/B glycosyltransferases (AT/BTs) and Forssman glycolipid synthase (FS) are encoded by the evolutionarily related $\mathrm{ABO}$ (A/B alleles) and GBGT1 genes [21,22]. It was shown that the FS is homologous to $\alpha-1,3$ GalNAc ABO A transferase ( $45 \%$ sequence identity), and, as a result of this identity, the product of this gene (the FS) cross-reacts with anti-A antibodies [23]. Forssman glycolipid synthetase (FS), is abundantly expressed on the surface of epithelial cells. In addition, van Genderen IL et al. have shown that FS is also localized in subcellular organelles. The Golgi complex, as well as endosomes and lysosomes, were positive for FS. Furthermore, the nuclear envelope was also Forssman positive, but the density was 10-fold less than on the plasma membrane; however, mitochondria and peroxisomes remained free of labels for FS [24]. While the antigenicity of carbohydrates has long been appreciated, when considering the ABO blood groups antigens, the presence of other types of anti-carbohydrate antibodies (ACAs) (such as Forssman antigens (FS Ag)) is poorly understood [25].

\section{Hypothesis}

Based on the published studies about the pathogenesis of COVID-19, we propose a hypothesis concerning the role of the Forssman blood system (Forssman antigen and anti-FORS antibodies) in COVID-19 pathogenesis.

\section{Explanation of Proposed Hypothesis}

\subsection{Forssman Synthetase}

Forssman synthase (FS) and glycosyltransferase A both result in the addition of the same terminal sugar, $\alpha-3-\mathrm{N}$-acetyl-d-galactosamine, while using different acceptors. The FS adds the terminal sugar to the $\mathrm{P}$ antigen, while glycosyltransferase $\mathrm{A}$ adds to the $\mathrm{H}$ antigen [26]. Previous studies reported that, in humans, the FS gene is presented as an inactive allele [27]. It was also shown that some people express the Forssman antigen due to a reversion in the Forssman synthetase gene. Thus, Forssman-positive individuals lack anti-Forssman antibodies [26]. Furthermore, Yamamoto et al. previously demonstrated that 
the replacement of the LeuGlyGly tripeptide sequence, from codons 266 to 268 of human AT with GBGT1-encoded FS-specific GlyGlyAla, enabled the enzyme to produce the FORS1 antigen [28]. In place of FS, humans produce the natural anti-Forssman antibody, which activates the complement system when interacting with the FS Ag. These can hemolyze FORS1+ erythrocytes in a complement dependent manner in vitro [29,30].

\subsection{Forssman Antigen and Diseases}

Taniguchi et al. reported that viral infection could lead to enzymatic activity of FS. This hypothesis was assayed in various human lymphoblastic cell lines. The activities of enzymes were found to increase by exposure of the lymphocytes to the Epstein-Barr virus (EBV) [31]. Moreover, the same group had reported that FS activity was higher in patients who suffered from squamous cell carcinomas (in 17 of 18). On the other hand, no increasing enzyme activities were reported in 28 adenocarcinomas [32].

Previous animal models have shown bronchoconstriction, thrombocytopenia, and endothelial cell damage, as well as pulmonary damage, induced by Forssman antibodies [33]. In this context, Nagai et al. reported pulmonary damage and an increase of lactate dehydrogenase (LDH) activity in animals with leukopenia and thrombopenia. Moreover, it has been shown that thromboxane synthase inhibitors reduce the Forssman antiserainduced cell damage [34]. Furthermore, Fan et al. reported that the GBGT1 gene in the peripheral blood of AMI patients was an upregulated gene in comparison to the control group [35]. In addition, epigenetic mechanisms such as DNA methylation, histone modification, chromatin remodeling, and non-coding RNAs (ncRNA) methylation probably play an important role for FS activation. Cooke describes that GBGT1 methylation plays a role in pathogenesis of both types of ulcerative colitis [36].

\section{Discussion}

Previously, researchers have shown that the ABO antigen's affiliation, beyond its necessity in daily transfusion medicine, constitutes an independent risk factor of cardiovascular diseases, neoplasm development, and infections [17,37-40]. Murray et al. report that $\mathrm{ABO}$ blood type antigens are expressed in von Willebrand factor (VWF) and that their glycosylation patterns influence circulating VWF levels, and, consequentially, thromboembolic complications [41].

The correlation between ABO blood types and the incidence of COVID-19, as well as disease outcomes, has been investigated in several studies $[39,42,43]$. Pourali et al., in a meta-analysis study, found that blood type A was a partial risk factor for COVID-19 infection, while blood type $\mathrm{O}$ was a protective factor [42]. Moreover, Marcos et al. suggest that patients with blood type $\mathrm{O}$ have lower susceptibility to infection, in contrast to type $\mathrm{B}$, who have a higher risk of complications [43].

Contrary to the ABO system, the clinical significance of the Forssman antigen, as well as anti-FORS antibodies, is still unknown to a large extent.

It was suggested that differential splicing and/or substitutions of the ABO gene may cause the ABO glycosyltransferase to make the FS structure [21]. Moreover, many blood type A individuals (in particular, A1) do not make anti-FORS antibodies. In addition, the upregulation of the GBGT1 gene is also implicated in pathogenesis of AMI. Furthermore, based on the knowledge that Forssman synthase uses P antigen as an acceptor, it would be interesting to investigate whether people who do not have P antigen will have a lower susceptibility to infection, similar to people with $\mathrm{P}$ phenotype, who are naturally resistant to parvovirus B19 infection [44].

Author Contributions: Conceptualization, T.G.K.; methodology, V.I.; formal analysis, T.G.K.; writing-original draft preparation, T.G.K. and V.I.; writing—review and editing, T.G.K.; supervision, G.M. and M.P. All authors have read and agreed to the published version of the manuscript.

Funding: This research received no external funding.

Institutional Review Board Statement: Not applicable. 
Informed Consent Statement: Not applicable.

Data Availability Statement: This data is available from the corresponding author on reasonable request.

Conflicts of Interest: The authors declare no conflict of interest.

\section{References}

1. Gorbalenya, A.E.; Baker, S.C.; Baric, R.S.; de Groot, R.J.; Drosten, C.; Gulyaeva, A.A.; Haagmans, B.L.; Lauber, C.; Leontovich, A.M.; Neuman, B.W.; et al. The Species Severe Acute Respiratory Syndrome-Related Coronavirus: Classifying 2019-NCoV and Naming It SARS-CoV-2. Nat. Microbiol. 2020, 5, 536-544. [CrossRef]

2. Weiss, S.R. Forty Years with Coronaviruses. J. Exp. Med. 2020, 217. [CrossRef] [PubMed]

3. Wu, A.; Peng, Y.; Huang, B.; Ding, X.; Wang, X.; Niu, P.; Meng, J.; Zhu, Z.; Zhang, Z.; Wang, J.; et al. Genome Composition and Divergence of the Novel Coronavirus (2019-NCoV) Originating in China. Cell Host Microbe 2020, 27, 325-328. [CrossRef] [PubMed]

4. Masters, P.S. The Molecular Biology of Coronaviruses. Adv. Virus Res. 2006, 66, 193-292. [CrossRef]

5. Lan, J.; Ge, J.; Yu, J.; Shan, S.; Zhou, H.; Fan, S.; Zhang, Q.; Shi, X.; Wang, Q.; Zhang, L.; et al. Structure of the SARS-CoV-2 Spike Receptor-Binding Domain Bound to the ACE2 Receptor. Nature 2020, 581, 215-220. [CrossRef]

6. Dveksler, G.S.; Dieffenbach, C.W.; Cardellichio, C.B.; McCuaig, K.; Pensiero, M.N.; Jiang, G.S.; Beauchemin, N.; Holmes, K.V. Several Members of the Mouse Carcinoembryonic Antigen-Related Glycoprotein Family Are Functional Receptors for the Coronavirus Mouse Hepatitis Virus-A59. J. Virol. 1993, 67, 1-8. [CrossRef] [PubMed]

7. Zhou, P.; Yang, X.-L.; Wang, X.-G.; Hu, B.; Zhang, L.; Zhang, W.; Si, H.-R.; Zhu, Y.; Li, B.; Huang, C.-L.; et al. A Pneumonia Outbreak Associated with a New Coronavirus of Probable Bat Origin. Nature 2020, 579, 270-273. [CrossRef]

8. Drosten, C.; Günther, S.; Preiser, W.; van der Werf, S.; Brodt, H.-R.; Becker, S.; Rabenau, H.; Panning, M.; Kolesnikova, L.; Fouchier, R.A.M.; et al. Identification of a Novel Coronavirus in Patients with Severe Acute Respiratory Syndrome. N. Engl. J. Med. 2003, 348, 1967-1976. [CrossRef]

9. Cauchemez, S.; Fraser, C.; Van Kerkhove, M.D.; Donnelly, C.A.; Riley, S.; Rambaut, A.; Enouf, V.; van der Werf, S.; Ferguson, N.M. Middle East Respiratory Syndrome Coronavirus: Quantification of the Extent of the Epidemic, Surveillance Biases, and Transmissibility. Lancet Infect. Dis. 2014, 14, 50-56. [CrossRef]

10. Zhu, N.; Zhang, D.; Wang, W.; Li, X.; Yang, B.; Song, J.; Zhao, X.; Huang, B.; Shi, W.; Lu, R.; et al. A Novel Coronavirus from Patients with Pneumonia in China, 2019. N. Engl. J. Med. 2020, 382, 727-733. [CrossRef] [PubMed]

11. WHO. Available online: https://www.who.int/docs/default-source/coronaviruse/situation-reports/20200727-covid-19-sitrep189.pdf?sfvrsn=b93a6913_2 (accessed on 27 July 2020).

12. Dömling, A.; Gao, L. Chemistry and Biology of SARS-CoV-2. Chem 2020, 6, 1283-1295. [CrossRef]

13. Yang, T.-Y.; Li, Y.-C.; Wang, S.-C.; Dai, Q.-Q.; Jiang, X.-S.; Zuo, S.; Jia, L.; Zheng, J.-B.; Wang, H.-L. Clinical Characteristics of Patients with COVID-19 Presenting with Gastrointestinal Symptoms as Initial Symptoms: Retrospective Case Series. World J. Clin. Cases 2020, 8, 2950-2958. [CrossRef] [PubMed]

14. Avila, J.; Long, B.; Holladay, D.; Gottlieb, M. Thrombotic Complications of COVID-19. Am. J. Emerg. Med. 2021, 39, 213-218. [CrossRef] [PubMed]

15. Skendros, P.; Mitsios, A.; Chrysanthopoulou, A.; Mastellos, D.C.; Metallidis, S.; Rafailidis, P.; Ntinopoulou, M.; Sertaridou, E.; Tsironidou, V.; Tsigalou, C.; et al. Complement and Tissue Factor-Enriched Neutrophil Extracellular Traps Are Key Drivers in COVID-19 Immunothrombosis. J. Clin. Invest. 2020, 130. [CrossRef]

16. Guillon, P.; Clément, M.; Sébille, V.; Rivain, J.-G.; Chou, C.-F.; Ruvoën-Clouet, N.; Le Pendu, J. Inhibition of the Interaction between the SARS-CoV Spike Protein and Its Cellular Receptor by Anti-Histo-Blood Group Antibodies. Glycobiology 2008, 18, 1085-1093. [CrossRef]

17. Cheng, Y.; Cheng, Y.; Cheng, G.; Chui, C.H.; Lau, F.Y.; Chan, P.K.S.; Ng, M.H.L.; Sung, J.J.Y.; Wong, R.S.M. ABO Blood Group and Susceptibility to Severe Acute Respiratory Syndrome. JAMA 2005, 293, 1450-1451. [CrossRef] [PubMed]

18. Severe Covid-19 GWAS Group; Ellinghaus, D.; Degenhardt, F.; Bujanda, L.; Buti, M.; Albillos, A.; Invernizzi, P.; Fernández, J.; Prati, D.; Baselli, G.; et al. Genomewide Association Study of Severe Covid-19 with Respiratory Failure. N. Engl. J. Med. 2020, 383, 1522-1534. [CrossRef]

19. Forssman, J. Die Herstellung Hochwertiger Spezifischer Schaf-Hamolysine Ohne Verwendung von Schafblut. Biochem. Z. 1911, 37, 78-115.

20. Haslam, D.B.; Baenziger, J.U. Expression Cloning of Forssman Glycolipid Synthetase: A Novel Member of the Histo-Blood Group ABO Gene Family. Proc. Natl. Acad. Sci. USA 1996, 93, 10697-10702. [CrossRef]

21. Cid, E.; Yamamoto, M.; Yamamoto, F. Blood Group ABO Gene-Encoded A Transferase Catalyzes the Biosynthesis of FORS1 Antigen of FORS System upon Met69Thr/Ser Substitution. Blood Adv. 2018, 2, 1371-1381. [CrossRef]

22. Yamamoto, M.; Cid, E.; Yamamoto, F. Molecular Genetic Basis of the Human Forssman Glycolipid Antigen Negativity. Sci. Rep. 2012, 2, 975. [CrossRef]

23. Barr, K.; Korchagina, E.; Popova, I.; Bovin, N.; Henry, S. Monoclonal Anti-A Activity against the FORS1 (Forssman) Antigen. Transfusion 2015, 55, 129-136. [CrossRef]

24. van Genderen, I.L.; van Meer, G.; Slot, J.W.; Geuze, H.J.; Voorhout, W.F. Subcellular Localization of Forssman Glycolipid in Epithelial MDCK Cells by Immuno-Electronmicroscopy after Freeze-Substitution. J. Cell Biol. 1991, 115, 1009-1019. [CrossRef] 
25. $\quad$ Luetscher, R.N.D.; McKitrick, T.R.; Gao, C.; Mehta, A.Y.; McQuillan, A.M.; Kardish, R.; Boligan, K.F.; Song, X.; Lu, L.; HeimburgMolinaro, J.; et al. Unique Repertoire of Anti-Carbohydrate Antibodies in Individual Human Serum. Sci. Rep. 2020, 10. [CrossRef]

26. Svensson, L.; Hult, A.K.; Stamps, R.; Ångström, J.; Teneberg, S.; Storry, J.R.; Jørgensen, R.; Rydberg, L.; Henry, S.M.; Olsson, M.L. Forssman Expression on Human Erythrocytes: Biochemical and Genetic Evidence of a New Histo-Blood Group System. Blood 2013, 121, 1459-1468. [CrossRef] [PubMed]

27. Yamamoto, M.; Cid, E.; Yamamoto, F. Crosstalk between ABO and Forssman (FORS) Blood Group Systems: FORS1 Antigen Synthesis by ABO Gene-Encoded Glycosyltransferases. Sci. Rep. 2017, 7, 41632. [CrossRef]

28. Yamamoto, M.; Cid, E.; Yamamoto, F. ABO Blood Group A Transferases Catalyze the Biosynthesis of FORS Blood Group FORS1 Antigen upon Deletion of Exon 3 or 4. Blood Adv. 2017, 1, 2756-2766. [CrossRef] [PubMed]

29. Galili, U. Human Natural Antibodies to Mammalian Carbohydrate Antigens as Unsung Heroes Protecting against Past, Present, and Future Viral Infections. Antibodies 2020, 9, 25. [CrossRef]

30. Hult, A.K.; Olsson, M.L. May the FORS Be with You: A System Sequel. Immunohematology 2020, 36, 14-18. [CrossRef]

31. Taniguchi, N.; Yanagisawa, K.; Makita, A.; Mizuno, F.; Osato, T. Globoside and Forssman Synthases in Human Lymphocytes Exposed to Epstein-Barr Virus and Mitogens. J. Natl. Cancer Inst. 1985, 74, 563-568. [PubMed]

32. Taniguchi, N.; Yokosawa, N.; Narita, M.; Mitsuyama, T.; Makita, A. Expression of Forssman Antigen Synthesis and Degradation in Human Lung Cancer. J. Natl. Cancer Inst. 1981, 67, 577-583.

33. Casacó, A.; Carvajal, D.; Friman, M.; Noa, M. Interference of Levamisole with Forssman Shock. Thromb. Res. 1990, 59, 629-637. [CrossRef]

34. Nagai, H.; Yakuo, I.; Inagaki, N.; Koda, A.; Hamano, S.; Ujiie, A.; Nakazawa, M. Role of Thromboxane (Tx) A2 in Guinea Pig Forssman Shock and the Effect of OKY-046, Tx A2 Synthetase Inhibitor. Prostaglandins Leukot. Med. 1987, 26, 133-141. [CrossRef]

35. Fan, L.; Meng, H.; Guo, X.; Li, X.; Meng, F. Differential Gene Expression Profiles in Peripheral Blood in Northeast Chinese Han People with Acute Myocardial Infarction. Genet. Mol. Biol. 2018, 41, 59-66. [CrossRef] [PubMed]

36. Cooke, J.; Zhang, H.; Greger, L.; Silva, A.-L.; Massey, D.; Dawson, C.; Metz, A.; Ibrahim, A.; Parkes, M. Mucosal Genome-Wide Methylation Changes in Inflammatory Bowel Disease. Inflamm. Bowel Dis. 2012, 18, 2128-2137. [CrossRef]

37. Cakir, U.; Tayman, C.; Buyuktiryaki, M. Unknown Aspects of the Relationship between ABO Blood Group System and Preterm Morbidities. Arch. Argent. Pediatr. 2020, 118, e135-e142. [CrossRef] [PubMed]

38. Franchini, M.; Bonfanti, C. Evolutionary Aspects of ABO Blood Group in Humans. Clin. Chim. Acta 2015, 444, 66-71. [CrossRef]

39. Li, J.; Wang, X.; Chen, J.; Cai, Y.; Deng, A.; Yang, M. Association between ABO Blood Groups and Risk of SARS-CoV-2 Pneumonia. Br. J. Haematol. 2020, 190. [CrossRef]

40. Wang, G.; Wang, H.; Shen, Y.; Dong, J.; Wang, X.; Wang, X.; Zheng, Y.; Guo, S. Association between ABO Blood Group and Venous Thrombosis Related to the Peripherally Inserted Central Catheters in Cancer Patients. J. Vasc. Access 2020, 1129729820954721. [CrossRef]

41. Murray, G.P.; Post, S.R.; Post, G.R. ABO Blood Group Is a Determinant of von Willebrand Factor Protein Levels in Human Pulmonary Endothelial Cells. J. Clin. Pathol. 2020, 73, 347-349. [CrossRef]

42. Pourali, F.; Afshari, M.; Alizadeh-Navaei, R.; Javidnia, J.; Moosazadeh, M.; Hessami, A. Relationship between Blood Group and Risk of Infection and Death in COVID-19: A Live Meta-Analysis. New Microbes New Infect. 2020, 37, 100743. [CrossRef] [PubMed]

43. Zalba Marcos, S.; Luisa Antelo, M.; Galbete, A.; Etayo, M.; Ongay, E.; García-Erce, J.A. Infection and Thrombosis Associated with COVID-19: Possible Role of the ABO Blood Group. Med. Clin. 2020, 155, 340-343. [CrossRef] [PubMed]

44. Brown, K.E.; Hibbs, J.R.; Gallinella, G.; Anderson, S.M.; Lehman, E.D.; McCarthy, P.; Young, N.S. Resistance to Parvovirus B19 Infection Due to Lack of Virus Receptor (Erythrocyte P Antigen). N. Engl. J. Med. 1994, 330, 1192-1196. [CrossRef] [PubMed] 